\section{MRS North Carolina Section Holds Workshop on Strained- Layer Semiconductors}

A very successful workshop on Growth and Characterization of Strained-Layer Semiconductors was held May 30, 1986 from 9:00 a.m. to 4:00 p.m. at the Carolina Inn, Chapel Hill, NC. The meeting, run like a mini-Gordon Conference, was organized and chaired by Wei-Kan Chu of the University of North Carolina. Dr. Salah Bedair (North Carolina State University), session chairman for the morning, led off the session devoted to Issues in Layered Semiconductor Growth. S.T. Picraux (Sandia National Laboratories) chaired the afternoon session, where recent work related to ion beam channeling was discussed.

Other papers were given by John Barrett (ORNL), Joze Bevk and Leonard Feldman (AT\&T Bell Laboratories), James Ellison (University of New Mexico), James Cook (North Carolina State University) and Michael Timmons (Research Triangle Institu te). About 35 to 40 scientists, including graduate students and senior professionals,

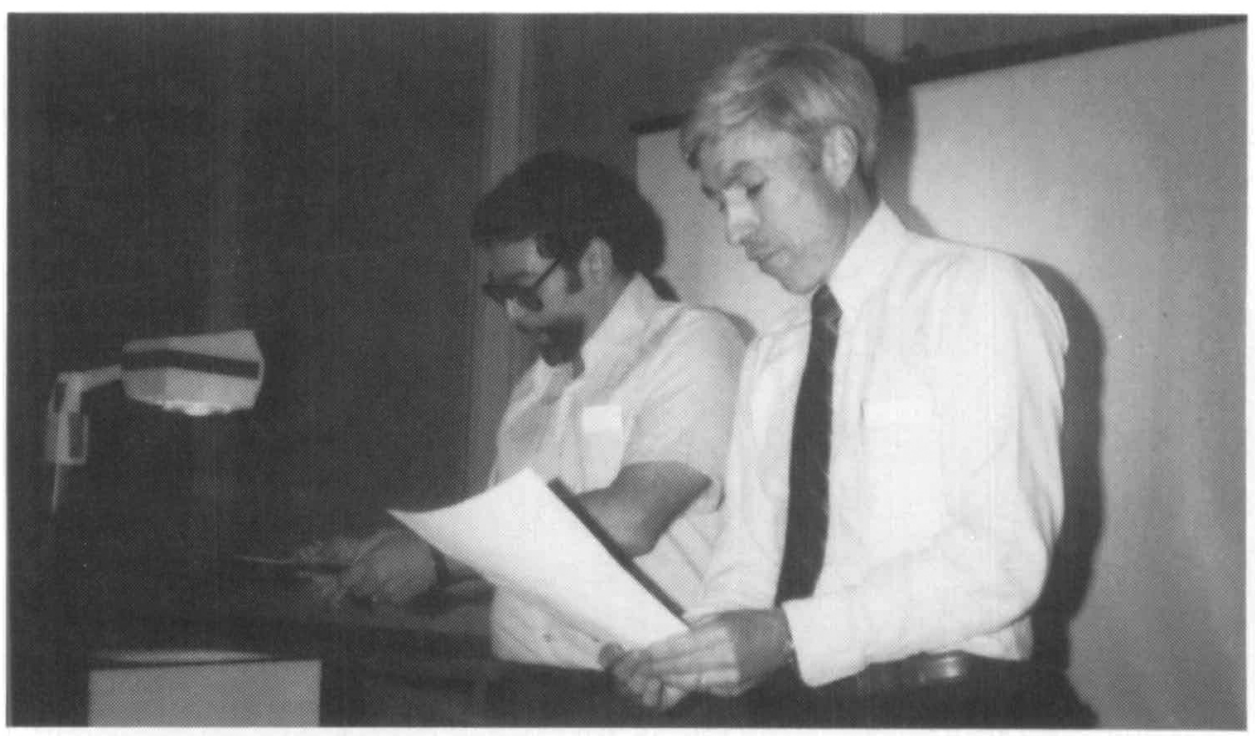

Leonard Feldman (left) and Tom Picraux address June workshop of North Carolina Section.

participated in the often very lively discussions. The workshop identified several problem areas related to strain, lattice mismatch, and growth where additional research is required. The evening before the workshop Dr. Chu hosted an informal reception for the 11 panel members and officers of the North Carolina Section.

\title{
ANNUAL REVIEW OF MATERIALS SCIENCE
}

\author{
Volume 16 \\ Edited by Robert A. Huggins \\ Publication: August 1986
}

As a member of the Materials Research Society, you may purchase the 1986 volume of Annual Review of Materials Science at a special price $-\$ 10$ off the publisher's retail price. This annual publication assesses current trends in materials science from an interdisciplinary viewpoint. Emphasis is on general aspects of structure, characterization, phenomena, and properties related to materials engineering. Published by Annual Reviews, Inc., this volume is an important summary of developments you need to know about. Order your copy now.

\section{ANNUAL REVIEW OF MATERIALS SCIENCE-VOLUME 16 Special MRS Member Discount}

I am a member of the Materials Research Society and wish to purchase Annual Review of Materials Science at the special member rate: $\quad \square$ MRS Member-US: \$54 $\square$ MRS Member-Foreign: \$57 Ship to:

Name

Institution

Address

City

State Zip Code

Country Telephone

Make check payable to Materials Research Society. Send order to Materials Research Society, Publications Department, 9800 McKnight Road, Suite 327, Pittsburgh, PA 15237; telephone (412) 367-3012. 


\section{Subscribe to}

\section{MATERIALS LETTERS}

\section{At Special MRS Member Rates}

As a member of the Materials Research Society, you can subscribe to Materials Letters at a special subscription rate. Only members of MRS may receive personal subscriptions to this valuable journal.*

Volume IV of Materials Letters will be completed during 1986. To receive the first issue of Volume $V$ as soon as it is published this year, subscribe now by completing the form below. For your convenience, you may also subscribe to Volume VI to ensure continuation of your subscription after Volume $V$ without pause in service.

*Institutional subscriptions for libraries must be obtained through the publisher, Elsevier Science Publishers B.V., Journal Department, P.O. Box 211,1000 AE Amsterdam, The Netherlands.

\section{MATERIALS LETTERS}

I am a member of the Materials Research Society and wish to subscribe to the following volumes of Materials Letters at the special MRS member personal subscription rate.

Check appropriate volume(s):

Volume IV (current volume) \& \$ $\$ 17.50$

Volume V \& \$20.00

$\$$

Volume $\mathrm{Vl}$ s $\$ 20.00$

$\$$

$\$$

TOTAL ENCLOSED

$\$$

Name

Organization

Address

City State Zip/Postal Code

Country

Return subscription order with payment to: Materials Letters Subscription, Materials Research Society, 9800 McKnight Road, Suite 327, Pittsburgh, PA 15237; telephone (412) 367.3012 